\title{
RADOSŁAW MĘDRZYCKI
}

Uniwersytet Kardynała Stefana Wyszyńskiego

\section{DZIAŁALNOŚĆ RZECZNIKA PRAW OBYWATELSKICH W POLSCE W ZAKRESIE OCHRONY OSÓB W KRYZYSIE BEZDOMNOŚCI I ZAGROŻONYCH BEZDOMNOŚCIĄ W LATACH 2005-2015 W ŚWIETLE RAPORTÓW RPO}

\section{UWAgi WSTĘPNE DOTYCZĄCE DZIAŁALNOŚCi RPO}

W doktrynie polskiego prawa administracyjnego trwa od kilku lat ożywiona dyskusja między innymi na temat stanu polskiej legislacji administracyjnej i wyzwań, przed którymi staje współczesny prawodawca ${ }^{1}$. Nie są to jednak, przy całej atomizacji współczesnego prawa administracyjnego, uwagi wyłącznie techniczne, skupione na wąsko zarysowanych obszarach prawa administracyjnego. Z dyskusji wyłania się zasadnicza, autentyczna troska wielu przedstawicieli doktryny prawa administracyjnego o fundamentalne sprawy aksjologiczne tego prawa ${ }^{2}$, a także dążenie do ochrony i stałej realizacji postulatu demokratycznego państwa prawnego ${ }^{3}$.

1 Por. np. cztery tomy publikacji pod red. D.J. Kijowskiego, P.J. SuwaJ, Kryzys prawa administracyjnego, Warszawa 2012; a także Prawo administracyjne. Dziś i jutro, red. J. JAGIELSKi, M. Wierzbowski, Warszawa 2018.

Aksjologia prawa administracyjnego, red. J. Zimmermann, Warszawa 2016.

I. Lipowicz, Kilka uwag $w$ kwestii racjonalności w prawie administracyjnym, [w:] Racjonalny ustawodawca. Racjonalna administracja. Pamięci Profesora Eugeniusza Smoktunowicza, red. D.J. Kijowski, A. Miruć, A. Budnik, Białystok 2016, s. 72. 
Sprawy te dotykają także rozważań stricte konstytucyjnych, w tym zasadniczych z punktu widzenia systemu ochrony praw i wolności jednostki ${ }^{4}$. W literaturze słusznie wskazuje się, że zwiększa się katalog podmiotów i dóbr chronionych przez Rzecznika, przy niezbyt adekwatnym do ich liczby i niezbyt zmienianym - mimo wielu lat istnienia instytucji - instrumentarium prawnym i kompetencjach ${ }^{5}$.

Z badawczego punktu widzenia szczególnie ciekawe jest spojrzenie na tę kwestię przez pryzmat działalności Rzecznika Praw Obywatelskich $^{6}$ - w Polsce centralnego, konstytucyjnego ${ }^{7}$ organu powołanego do stania na straży wolności i praw człowieka i obywatela określonych w Konstytucji oraz w innych aktach normatywnych, w tym również realizacji zasady równego traktowania ${ }^{8} \mathrm{w}$ obszarze ochrony osób w kryzysie bezdomności.

$\mathrm{Z}$ prawnego punktu widzenia prima facie organ ten dysponuje zasadniczo dość szerokim spektrum środków oddziaływania, przy czym pozostawiamy poza analizą problematykę ich władczości oraz - co w ostatnich czasach niestety ma miejsce - braku korelacji między rosnącą liczbą obowiązków (zadań) Rzecznika a wysokością budżetu tego urzędu. To odrębny, wymagający dodatkowych, pogłębionych badań problem.

4 Por. np.: I. Malinowska, Rzecznik Praw Obywatelskich w systemie ochrony wolności i praw obywatelskich, Warszawa 2007; M. ZuвІк, Rzecznik Praw Obywatelskich (po 20 latach istnienia urzędu), «PiP» 63.11/2008, s. 3-19; M. WRóBLEWsKI, Ochrona praw osób starszych $w$ działalności Rzecznika Praw Obywatelskich jako krajowej instytucji ochrony praw człowieka, «RPEiS»74.3/2012, s. 123-138; A. BŁAszczAK, Efektywność środków ochrony przed dyskryminacją w Polsce, «PiP» 70.6/2015, s. 37-50.

5 N. Banaszak, Skuteczność działania Rzecznika Praw Obywatelskich - podstawowe problemy, «Studia Lubuskie»5/2009, s. 77. Należy wskazać, że ustawa z 15 lipca 1987 r. o Rzeczniku Praw Obywatelskich (tekst jedn.: Dz. U. z 2017 r. poz. 958 ze zm.) była zmieniana ponad 15 razy, jednak większość zmian nie dotyczyła kompetencji RPO.

6 Dalej także jako Rzecznik albo RPO.

7 M. Szubiakowski, Administracyjnoprawna regulacja praw $i$ wolności obywatelskich, Warszawa 2017.

8 Por. art. 208 ust. 1 Konstytucji Rzeczypospolitej Polskiej z 2 kwietnia 1997 r., Dz. U. Nr 78, poz. 483 ze zm. 
Jednym ze środków ochrony wolności i praw przewidzianych w polskiej Konstytucji jest możliwość wystąpienia przez każdego, na zasadach określonych w ustawie ${ }^{9}$, do Rzecznika Praw Obywatelskich z wnioskiem o pomoc w ochronie swoich wolności lub praw naruszonych przez organy władzy publicznej (art. 80 Konstytucji). Rzecznik, poza uprawnieniami procesowymi związanymi z tą ochroną, dysponuje także możliwością wpływu na istniejącą regulację prawną za pomocą: „nacisku" na podmioty uprawnione do wystąpienia z inicjatywą ustawodawczą, inicjowanie oceny konstytucyjności norm prawnych przez Trybunał Konstytucyjny, występowanie do Sądu Najwyższego i Naczelnego Sądu Administracyjnego $\mathrm{z}$ wnioskiem o podjęcie uchwał abstrakcyjnych, a także podjęcie uchwał dotyczących przepisów budzących rozbieżności w doktrynie i orzecznictwie ${ }^{10}$. Pozytywne skutki ochrony praw człowieka przez Rzecznika będą widoczne jednak wyłącznie przy zdrowych podstawach funkcjonowania władz publicznych i współpracy między nimi. Ustawodawca musi także zapewnić w tym względzie odpowiednie instrumentarium prawne.

Z pola widzenia nie może umknąć również fakt, że rolą Rzecznika jest nie tylko troska o przestrzeganie obowiązujących w porządku wewnętrznym praw człowieka (funkcja ochronna) - te mogą być (chociaż nie powinny) przecież znacząco ograniczane przez władzę ustawodawczą. Chodzi także o funkcję postulatywną, związaną z zabieganiem o wciąż wyższe standardy ochrony praw człowieka.

Można zadać zatem pytanie, dlaczego mimo ponad 30 lat funkcjonowania tego organu istnieje swoista stagnacja w rozwiązywaniu szczególnie dotkliwych społecznie problemów. Jaka jest główna przyczyna tego stanu rzeczy? Czy zawodzi słabe „oprogramowanie” prawne, w które został wyposażony Rzecznik? A może problemem jest tu jedna $\mathrm{z}$ form jego działania?

Celem artykułu jest analiza działalności Rzecznika w zakresie ochrony praw osób w kryzysie bezdomności. Bezdomność jest ważnym poznawczo

9 Ustawa z 15 lipca 1987 r. o Rzeczniku Praw Obywatelskich (tekst jedn.: Dz. U z 2017 r. poz. 958 ze zm.).

10 M. Szubiakowski, op. cit., przyp. 7. 
obszarem referencyjnym, gdyż jako jeden z rodzajów wykluczenia społecznego stanowi szczególny splot problemów indywidualnych i społecznych wpływających na funkcjonowanie praw człowieka ${ }^{11}$. Ze zjawiskiem bezdomności łączy się wiele problemów prawnych, które - mimo zmian kadencji sejmowych i składów rządów - wydają się takie same.

Aby odpowiedzieć na pytania badawcze, przedmiotem analizy uczyniono informacje (raporty) o działalności Rzecznika Praw Obywatelskich ${ }^{12}$. Posłużono się także metodą dogmatycznoprawną. Zgodnie z art. 202 Konstytucji: Rzecznik Praw Obywatelskich corocznie informuje Sejm i Senat o swojej działalności oraz o stanie przestrzegania wolności i praw człowieka i obywatela. Przedkłada w tym celu równolegle z ustną informacją na parlamentarnych komisjach i posiedzeniach Sejmu i Senatu informację o stanie przestrzegania wolności i praw człowieka i obywatela ${ }^{13}$. Informacja ta jest interesująca badawczo, gdyż stanowi swoiste podsumowanie rocznej pracy Rzecznika, która obejmuje różne formy jego aktywności, w tym informację o działaniach indywidualnych, jak i wystąpieniach generalnych. Analiza poszczególnych form działania Rzecznika była już przedmiotem zainteresowania w literaturze ${ }^{14}$.

Za cezurę badań przyjęto okres 10 lat, tj. 2005-2015, choć w artykule znajduje się też analiza informacji (raportów) RPO z lat wcześniejszych w celu wskazania ewentualnej zmiany problemów diagnozowanych przez Rzecznika. Rok 2005 to nie tylko formalny koniec kadencji czwartego Rzecznika, lecz także pierwszy rok obowiązywania nowej ustawy z 12 marca 2004 r. o pomocy społecznej, tak ważnej dla ochrony praw

11 R. MęDrZYCKI, Zadania administracji publicznej w zakresie przeciwdziałania bezdomności - studium administracyjnoprawne, Warszawa 2017, s. 307.

12 Informacje te i opis działalności RPO są wydawane przez Biuro RPO w postaci Biuletynu RPO. Ze względu na zbiorowy charakter opracowań oraz zasadniczy brak typowych śródtytułów charakterystycznych dla czasopism naukowych występują one w przypisach bez nazwisk ich twórców. Przyjąć bowiem należy, że jest nim autor zbiorowy lub zatrudniony w BRPO. Zrezygnowano tym samym również ze wskazywania zakresu artykułów, numerów stron w wykazie cytowanej literatury.

13 S. Trociuk, Rzecznik Praw Obywatelskich. Komentarz, Warszawa 2007.

14 K. NalAsKowsKi, Sposób wykorzystania kompetencji przez Rzeczników w latach 1987-2007, [w:] Księga XX-lecia Rzecznika Praw Obywatelskich w Polsce, red. M. Zubiк, Warszawa 2008. 
osób w kryzysie bezdomności. Okres 10 lat stanowi zamknięty okres działalności Rzecznika dwóch kadencji, jednocześnie obejmuje różne większości parlamentarne i różne składy rządów, umożliwia zatem dokonanie, wolnej od politycznych ocen, obiektywnej analizy. Poza rozważaniami pozostawiam okres obecnej kadencji Rzecznika, brak jej zakończenia uniemożliwia dokonanie całościowej oceny.

\section{OCHRONA PRAW OSÓB W KRYZYSIE BEZDOMNOŚCI W DZIAŁALNOŚCI RPO PRZED 2005 R.}

Rzecznik Praw Obywatelskich od początku funkcjonowania urzędu (utworzenie 1 stycznia 1988 r.) wielokrotnie zwracał uwagę na problematykę osób bezdomnych lub zagrożonych bezdomnością. Dla Rzecznika oczywiste było, że: „osobom bezdomnym, podobnie jak wszystkim obywatelom przysługują prawa i wolności obywatelskie, określone w Konstytucji”"15, zaś sama administracja powinna wykorzystywać istniejące mechanizmy prawne.

Już w początkowych latach swojego funkcjonowania organ ten występował z krytycznymi uwagami dotyczącymi sytuacji mieszkaniowej w Polsce, w tym w szczególności problemami budownictwa socjalnego $^{16}$. W 1994 r. opublikowano krytyczny „Raport o stanie prawa mieszkaniowego w świetle praktyki Rzecznika Praw Obywatelskich"17.

W 1997 r. Rzecznik zwrócił uwagę Prezesa Rady Ministrów na brak systemowej regulacji prawnej pozwalającej zaspokoić sytuację mieszkaniową wielu osób, w szczególności brak ustawy umożliwiającej finansowanie budownictwa socjalnego dla obywateli znajdujących się w niedostatku ${ }^{18}$. W kolejnym wystąpieniu do Prezesa Rady Ministrów

15 «Biuletyn RPO. Materiały» 27/1995, s. 75.

16 «Biuletyn RPO. Materiały» 2/1988, s. 17-20; «Biuletyn RPO. Materiały» 9/1990, s. $69-72$.

17 «Biuletyn RPO. Materiały» 20/1994, s. 5-33.

18 «Biuletyn RPO. Materiały» 33/1997, s. 141. W odpowiedzi RPO uzyskał odpowiedź odmowną - administracja rządowa stwierdziła, że nieuzasadnione jest tworzenie mieszkań o obniżonej wartości użytkowej. 
z 24 marca 1997 r. Rzecznik wskazywał, że liberalizacja przepisów eksmisyjnych przy braku rozwiązań prawnych stymulujących rozwój budownictwa socjalnego będzie sprzyjać rozszerzaniu się zjawiska bezdomności ${ }^{19}$.

Kwestia niewystarczającego budownictwa socjalnego była przedmiotem troski Rzecznika również w kolejnych latach. W 2001 r. organ ten diagnozował wciąż niezadowalający stan prawny budownictwa socjalnego w Polsce, co przy nikłych mechanizmach zapobiegania bezdomności unormowanych ustawą o ochronie praw lokatorów czyniło iluzorycznym przeciwdziałanie bezdomności. Rzecznik zauważył, że gminy nie mają środków na rozwój takiego budownictwa, nie są zatem w stanie samodzielnie realizować dyspozycji art. 75 ust. 1 Konstytucji ${ }^{20}$. Przepis ten również współcześnie stanowi podstawową wytyczną dla władz publicznych w zakresie przeciwdziałania bezdomności ${ }^{21}$.

W 2003 r. Rzecznik wciąż diagnozował brak rozwiązań systemowych w zakresie budownictwa socjalnego ${ }^{22}$. Wydawało się, że sytuacja uległa zmianie w 2004 r. wraz z przyjęciem regulacji ułatwiających rozwój budownictwa socjalnego ${ }^{23}$, jednakże już rok później Rzecznik wskazywał na dalszą potrzebę „ożywienia” tego budownictwa ${ }^{24}$.

Od początku funkcjonowania urzędu Rzecznik zwracał szczególną uwagę na kwestie meldunku. Są one silnie powiązane z sytuacją bezdomności. Należy wskazać, że - pomimo zmian prawnych - nieodmiennie od 28 lat ustawodawca wiąże pojęcie osoby bezdomnej z meldunkiem²5.

$\begin{array}{ll}19 & \text { Ibidem, s. } 142 . \\ 20 & \text { «Biuletyn RPO. Materiały» 44/2002, s. 239-240. } \\ 21 & \text { „Władze publiczne prowadzą politykę sprzyjającą zaspokojeniu potrzeb miesz- }\end{array}$ kaniowych obywateli, w szczególności przeciwdziałają bezdomności, wspierają rozwój budownictwa socjalnego oraz popierają działania obywateli zmierzające do uzyskania własnego mieszkania”.

22 «Biuletyn RPO. Materiały» 48/2004, s. 373.

23 «Biuletyn RPO. Materiały» 50/2005, s. 352.

24 «Biuletyn RPO. Materiały» 52/2006, s. 280.

25 Definicja osoby bezdomnej zawarta w ustawie z 29 listopada 1990 r. o pomocy społecznej (tekst jedn.: Dz. U. z 1998 r. Nr 64, poz. 414 ze zm.) brzmiała: osoba niezamieszkująca w lokalu mieszkalnym w rozumieniu przepisów o najmie lokali mieszkalnych i dodatkach mieszkaniowych i nigdzie niezameldowaną na pobyt stały 
Już w 1988 r. RPO wystąpił do organów państwowych z apelem o dostosowanie przepisów ustawy o ewidencji ludności i dowodach osobistych do słusznych potrzeb obywateli. Rzecznik diagnozował, że regulacje prawne ograniczają prawa osoby z brakiem meldunku (a więc także osoby bezdomne) do ochrony zdrowia, pracy, nauki, prawa do otrzymania mieszkania w miejscowości, w której ta osoba nie jest zameldowana ${ }^{26}$. Do Rzecznika zgłaszano sytuacje odmowy zatrudnienia $\mathrm{z}$ powodu braku meldunku ${ }^{27}$ lub odmowy wydania dowodu osobistego ${ }^{28}$.

Początek lat 90. przyniósł wzrost liczby listów kierowanych do Rzecznika dotyczących ogólnej sytuacji w kraju, które przejawiały niepokój związany z utratą bezpieczeństwa społecznego (socjalnego). Chodziło głównie o utratę pracy i zagrożenie jej utratą, zagrożenie utratą mieszkania połączone z niemożliwością uzyskania mieszkania spółdzielczego z powodu drożyzny oraz pętli kredytowej ${ }^{29}$. Sam Rzecznik podkreślał niebezpieczeństwa związane z odbieraniem książeczek mieszkaniowych osobom skazanym, co stanowiło w konsekwencji „życiową dotkliwość pozbawienia szansy na mieszkanie" ${ }^{30}$. Było to swego rodzaju przyczynianie się państwa do trudnej sytuacji osób opuszczających zakłady karne, a w konsekwencji także do bezdomności.

W Polsce - nieodmiennie również dzisiaj - podstawową pomoc osobom bezdomnym de iure zapewnia gmina. Jedną $\mathrm{z}$ form tej pomocy jest zapewnienie schronienia osobom bezdomnym. W $1995 \mathrm{r}$. Rzecznik przeprowadził wizytacje i rozmowy w schroniskach dla osób

w rozumieniu przepisów o ewidencji ludności i dowodach osobistych (art. 2a ust. 1 pkt 5a). Definicja osoby bezdomnej zawarta w ustawie z 12 marca 2004 r. o pomocy społecznej (tekst jedn.: Dz. U. z 2018 r. poz. 1508 ze zm.) brzmi: osoba niezamieszkująca w lokalu mieszkalnym w rozumieniu przepisów o ochronie praw lokatorów i mieszkaniowym zasobie gminy i niezameldowana na pobyt stały, w rozumieniu przepisów o ewidencji ludności, a także osoba niezamieszkująca w lokalu mieszkalnym i zameldowana na pobyt stały w lokalu, w którym nie ma możliwości zamieszkania (art. 6 pkt 8).

26 «Biuletyn RPO. Materiały» 21/1994, s. 107.

$27 \mathrm{RPO} / 119772 / 93 / \mathrm{V}$.

$28 \mathrm{RPO} / 130095 / 93 / \mathrm{V}$.

29 «Biuletyn RPO. Materiały» 12/1991, s. 27.

30 «Biuletyn RPO. Materiały» 9/1990, s. 70. 
bezdomnych ${ }^{31}$. Na podstawie zebranego materiału empirycznego powstał „Raport Rzecznika Praw Obywatelskich w sprawie wykonania przez gminy ustawowych obowiązków wobec osób bezdomnych" ${ }^{2}$, w którym stwierdzono, że stan wykonywania przez gminy obowiązków w stosunku do osób bezdomnych jest tylko dostateczny ${ }^{33}$. Stwierdzono, że przepisem przyczyniającym się do bezdomności był art. 15 ust. 2 ustawy z 10 kwietnia 1974 r. o ewidencji ludności i dowodach osobistych ${ }^{34}$, pozwalający na wymeldowanie „donikąd”.

$\mathrm{W}$ raporcie konkludowano, $\dot{\mathrm{z}} \mathrm{e}^{35}$ :

1. pomoc osobom bezdomnym w gminach nie ma charakteru zaawansowanego, lecz sprowadza się do prostego przyznawania zasiłków czy zapomóg;

2. częstymi przypadkami było przerzucanie ze szpitali na schroniska odpowiedzialności za schorowane osoby bezdomne ${ }^{36}$;

3. gminy podejmowały współpracę nad zapewnieniem opieki nad osobami bezdomnymi z organizacjami pozarządowymi bądź przez dofinansowywanie zadań lub przekazanie do nieodpłatnego korzystania budynku komunalnego; mechanizmy są również współcześnie wbudowane w polskie ustawodawstwo ${ }^{37}$.

31 «Biuletyn RPO. Materiały» 27/1995, s. 73-102.

32 RPO/177262/95/X/DG.

33 «Biuletyn RPO. Materiały» 27/1995, s. 99.

34 Przepis ten brzmiał: „Terenowy organ administracji państwowej wydaje na wniosek strony lub z urzędu decyzję w sprawie wymeldowania osoby, która utraciła uprawnienie wymienione w art. 9 ust. 2 i bez wymeldowania się opuściła dotychczasowe miejsce pobytu stałego, albo osoby, która bez wymeldowania się opuściła dotychczasowe miejsce pobytu stałego i nie przebywa w nim co najmniej przez okres 6 miesięcy, a nowego miejsca jej pobytu nie można ustalić”.

35 «Biuletyn RPO. Materiały» 27/1995, s. 80-99.

36 Do kwestii tej powrócił RPO w 2001 r., gdy podnosił, że wciąż istnieją trudności w zapewnieniu opieki medycznej osobom bezdomnym, występując jednocześnie do Ministra Pracy i Polityki Społecznej o stworzenie systemu organizacyjno-finansowego opieki medycznej nad osobami bezdomnymi; «Biuletyn RPO. Materiały» 44/2002, s. 181.

37 Por. np. A. Miruć, Współdziałanie podmiotów zajmujących siępomocą społeczną, [w:] Formy współdziałania jednostek samorządu terytorialnego, red. B. DoLnICKI, Warszawa 2012, s. 52 i n. 
Autorzy raportu ocenili także warunki przebywania osób bezdomnych w schroniskach. W tym zakresie wskazano, że w schroniskach dla kobiet $\mathrm{z}$ dziećmi istniały dobre warunki do przebywania, a także zapewniały one wystarczającą przestrzeń i sprzęty; pozytywnie oceniono również zapewnienie kobietom z dzieckiem lub dziećmi osobnego pokoju. W przeciwieństwie do dobrego wyposażenia schronisk dla kobiet z dziećmi stwierdzono bardzo zróżnicowane wyposażenie w placówkach dla bezdomnych kobiet i mężczyzn. Wskazano, że niekorzystnie na spokój i bezpieczeństwo osób bezdomnych przebywających w placówkach wpływa bliskość izby wytrzeźwień. Zdiagnozowano również nieodpowiednie zabezpieczenie placówek dla kobiet z dziećmi, które były narażone na ataki agresji ze strony porzuconych partnerów (w wyniku ataków kilkukrotnie doszło do pobicia kierowniczek ośrodka). Osoby bezdomne nie miały wielokrotnie dostępu do regulaminów placówek, z których mogłyby czerpać wiedzę o swoich prawach lub obowiązkach, ewentualnie dochodzić na ich podstawie swoich praw.

Autorzy raportu konkludowali, że główne obciążanie zadaniami pomocy osobom bezdomnym gmin jest niewłaściwe, ponieważ bezdomność jest zjawiskiem ponadlokalnym.

Działalność Rzecznika wiązała się również z analizą stanu więziennictwa oraz problemów pomocy postpenitencjarnej dla osób dorosłych w Polsce ${ }^{38}$. Zagadnienie to dotyczy tzw. bezdomności potencjalnej, którą objęte są niektóre osoby przebywające w zakładach administracyjnych ${ }^{39}$. Osoby takie po opuszczeniu zakładu, na przykład więzienia, stają się faktycznie osobami bezdomnymi. Do ich bezdomności przyczyniają się między innymi brak znajomości środków prawnych, brak zarobków w więzieniu, które umożliwiłyby stałe regulowanie należności czynszowych. „Ze skarg - pisano w 1994 r. - które napływają do RPO, wynika, że wielu pozbawionych wolności traci mieszkania w czasie

38 «Biuletyn RPO. Materiały» 24/1994, s. 49-91; zob. tė̇ węzłowe problemy polskiego więziennictwa - części 1-4, publikowane kolejno w «Biuletyn RPO. Materiały» 28/1995; 32/1997; 34/1998; 42/2000. Por. też Wykonywanie środków probacji i readaptacji skazanych w Polsce, red. J. ZaGórski, Warszawa 2008.

39 A. Przymeński, Bezdomność jako kwestia społeczna w Polsce współczesnej, Poznań 2001, s. 37-38. 
pobytu w zakładzie karnym lub też zostaje pozbawionych możliwości powrotu do dotychczasowego lokum" ${ }^{\prime 40}$.

\section{OCHRONA PRAW OSÓB W KRYZYSIE BEZDOMNOŚCI W DZIAŁALNOŚCI RPO PO 2005 R.}

W analizowanym okresie Rzecznik podejmował wiele kwestii związanych z problemami bezdomności. Należy zauważyć, że nie działał on jednak wyłącznie w sferze ochrony praw osób bezdomnych, ale także zagrożonych bezdomnością. Stąd na przykład od 2007 r. Rzecznik podejmował generalne wystąpienia w kwestii „ujednolicenia standardów ochrony wszystkich praw lokatorów przed bezdomnością". Chodziło o kwestie braku zapewnienia prawa do lokalu socjalnego lub pomieszczenia tymczasowego dla osób poddanych obowiązkowi opróżnienia lokalu w trybie egzekucji administracyjnej. Inaczej niż w przypadkach osób poddawanych takiej egzekucji w trybie cywilnym, ustawodawca nie przewidywał tożsamej ochrony przed bezdomnością poprzez przyznanie lokalu socjalnego lub pomieszczenia tymczasowego. Kwestia ta stała się podstawą wystąpienia generalnego RPO do Prezesa Rady Ministrów (pismo z 23 kwietnia 2013 r., RPO-529615/06) i Ministra Spraw Wewnętrznych (pismo z 14 maja 2015 r., IV.7214.131.2014). Jest symptomatyczne, ale i skłania do odpowiedzi na postawione na wstępie artykułu pytanie o powody stagnacji w wielu kwestiach ochrony praw człowieka mimo działalności Rzecznika, że sytuacja związana z kwestią ujednolicenia standardów ochrony lokatorów w wyniku wyroku eksmisyjnego nastąpiła dopiero wskutek dostosowania przepisów w wyniku wyroku Trybunału Konstytucyjnego z 18 października 2017 r. (K 27/15) ${ }^{41}$. Jest to wyraźny sygnał, że zawodzi nie tyle swoiste „oprogramowanie prawne”, w jakie został wyposażony Rzecznik diagnozujący przecież dysfunkcje prawne, ile „oprogramowanie” organów ustawodawczych,

\footnotetext{
40 «Biuletyn RPO. Materiały» 24/1994, s. 82.

${ }_{41}$ Z wnioskiem do Trybunału Konstytucyjnego 9 października 2015 r. wystąpił Rzecznik Praw Obywatelskich.
} 
które mogą zostawać swoiście „głuche” na postulaty zmiany prawa, zasadniczo bez prawnych konsekwencji.

Klarowne wyróżnienie działań podejmowanych w zakresie przeciwdziałania bezdomności jest czasami utrudnione ze względu na to, że bezdomność nie jest prostym skutkiem z góry określonej sytuacji, na przykład utraty pracy. Związane są z tym także inne problemy, których prawna i społeczna diagnoza była przedmiotem działalności RPO. W tym kontekście należy wskazać dużą liczbę publikacji specjalistycznych i poradnikowych wydawanych w okresie 2010-2015 w Biurze Rzecznika Praw Obywatelskich. Wymienić należy publikacje w ramach serii „Zasada Równego Traktowania. Prawo i Praktyka”, szczególnie Przeciwdziałanie przemocy wobec kobiet, w tym kobiet starszych $i$ kobiet $z$ niepetnosprawnościami (Warszawa 2013), Wsparcie osób chorujących psychicznie na rynku pracy. Analiza i zalecenia (Warszawa 2014) czy monografie poświęcone osobom starszych (np. Strategie działania w starzejącym się społeczeństwie. Tezy i rekomendacje, Warszawa 2012). Do istotnych publikacji popularyzatorskich należy zaliczyć cykl poradników, na przykład Usługi finansowe. Poradnik dla osób starszych", czy Prawa człowieka. Poradnik dla osób starszych).

Istotnym elementem wspomagającym działalność Rzecznika była bezpłatna infolinia o przysługujących danej osobie prawach i sposobie złożenia wniosku do RPO (800 676 676). Jej uruchomienie należy traktować jako ważny element edukacji o przysługujących każdemu prawach, a także pierwszy etap pomocy.

Kontynuując analizę raportów i wystąpień RPO, należy podkreślić, że koncentrowały się one, podobnie jak w pierwszym z opisywanych okresów, na problemach mieszkaniowych. Rzecznik odniósł się do nich między innymi w 2010 r. Diagnozował wtedy brak odpowiedniej liczby mieszkań oraz środków na budowę lub pozyskanie nowych lokali. Stwierdzał też, że sytuację tę może poprawić długookresowy program rozwoju budownictwa mieszkaniowego, określający w szczególności zasady wsparcia finansowego dla gmin $^{42}$.

42 «Biuletyn RPO. Źródła» 1/2011, s. 197. 
Przykładem, że rolą Rzecznika jest dbanie o prawa każdej grupy społecznej, jest zwrócenie przez ten organ uwagi na konflikt między prawem własności a wymogiem przeciwdziałania bezdomności (2012). Konflikt ten rodzi brak wystarczającej liczby lokali socjalnych, których zapewnienie w przypadku eksmisji spoczywa na gminach. Do Rzecznika wpłynęło wiele skarg od właścicieli mieszkań, którzy czekali na realizację prawomocnych wyroków eksmisyjnych, których wykonanie było uzależnione od dostarczenia przez gminę właściwego lokalu socjalnego. „Zgodnie z ustawą o ochronie praw lokatorów możliwość realizacji wyroku eksmisyjnego w trybie egzekucji sądowej zostaje wstrzymana do momentu złożenia dłużnikowi przez gminę oferty zawarcia umowy najmu lokalu socjalnego. Ustawa nie przewiduje terminu końcowego wstrzymania postępowania egzekucyjnego. Tymczasem, ze względu na ciągły brak wystarczającej liczby lokali socjalnych, oczekiwanie na wyegzekwowanie wyroku eksmisyjnego stale się wydłuża. Taki stan rzeczy można uznać za nadmierną ingerencję w prawo własności. Sytuacja, w której w rozsądnym do przewidzenia terminie nie jest możliwa realizacja prawomocnego wyroku sądowego, może być postrzegana także jako naruszenie prawa do sądu. Wiele gmin nie podejmuje uchwał w sprawie zasad gospodarowania mieszkaniowym zasobem. Obowiązujące prawo nie przewiduje żadnych środków przymuszenia gminy do podjęcia takiej uchwały. Ponadto pomoc finansowa państwa na budownictwo socjalne jest niewystarczająca i nie zachęca do podejmowania przez gminy nowych inwestycji. Z jednej strony państwo, przeciwdziałając bezdomności, nałożyło na właścicieli mieszkań obowiązek znoszenia przez nieokreślony czas istotnego ograniczenia prawa własności, z drugiej zaś - nie stworzyło skutecznych mechanizmów mobilizujących gminy do realizowania budownictwa socjalnego"43.

W swojej działalności Rzecznik zwracał wciąż też uwagę na wady systemu opieki zdrowotnej dla osób bezdomnych.

W 2010 r. Rzecznik ukazał brak równości w dostępie do świadczeń medycznych dla osób bezdomnych. Organ ten zakwestionował zgodność art. 54 ustawy o świadczeniach zdrowotnych finansowanych ze

43 «Biuletyn RPO. Źródła» 1/2013, s. 153. 
środków publicznych z art. 68 ust. 2 Konstytucji, stwierdzając, że prawo do świadczeń zdrowotnych uzależnione jest dla obywatela polskiego od jego sytuacji majątkowej. Rzeczony przepis ustawowy wymaga spełnienia kryteriów dochodowych określonych w przepisach ustawy o pomocy społecznej ${ }^{44}$. W następnym roku Rzecznik po raz kolejny podniósł problem wadliwości rozwiązań prawnych w zakresie opieki medycznej dla osób bezdomnych, koncentrując się na osobach bezdomnych, które nie korzystają z rozwiązań pomocy społecznej. „Uzyskanie świadczeń zdrowotnych na podstawie powyższych regulacji poprzedzone jest sformalizowaną i skomplikowaną procedurą, zupełnie niedostosowaną do istoty bezdomności. Istnieje bowiem grupa osób bezdomnych, która nie podejmie żadnych działań w kierunku uzyskania podstaw do korzystania ze świadczeń pomocy społecznej oraz opieki zdrowotnej finansowanych ze środków publicznych. Niezbędne są zatem rozwiązania systemowe, które pozwolą na objęcie tych osób opieką medyczną. Zdaniem Rzecznika owe rozwiązania systemowe powinny polegać na stworzeniu podstaw prawnych oraz zapewnieniu źródeł i sposobu finansowania niezbędnych świadczeń medycznych oraz uproszczeniu procedur dostępu osób bezdomnych i nieubezpieczonych do zakładów opiekuńczo-leczniczych i zakładów pielęgnacyjno-opiekuńczych oraz domów pomocy społecznej"45.

\section{Podsumowanie I WNiOski}

W literaturze słusznie zauważa się, że bezdomność „wymusza w różnym stopniu przemiany administracji i inicjuje procesy dostosowawcze w jej strukturze organizacyjnej, w sposobach czy standardzie realizowanych przez nią zadań"46. Rolą Rzecznika było zawsze dostrzegać i sygnalizować ustawodawcy i administracji potrzeby takich zmian.

44 «Biuletyn RPO. Źródła» 1/2011, s. 149.

45 «Biuletyn RPO. Źródła»1/2012, s. 117.

46 D. CENDRowicz, Osoba bezdomna jako element społecznego otoczenia administracji publicznej, «Acta Universitatis Vratislaviensis. Przegląd Prawa i Administracji» 111/2017, s. 24. 
To właśnie coroczne informacje Rzecznika należy uznać za jedną z najważniejszych form ochrony praw człowieka w wymiarze generalnym.

Działania Rzecznika Praw Obywatelskich zabiegały o poprawę sytuacji osób bezdomnych w Polsce między innymi przez interwencje dotyczące zmian legislacyjnych. Rzecznik w swojej dotychczasowej działalności kładł szczególny nacisk na kwestie budownictwa socjalnego, standardów pomocy osobom bezdomnym oraz opieki zdrowotnej dla tych osób. O ile w pierwszych latach funkcjonowania urzędu bezdomność pojawiała się najczęściej w kontekście sytuacji mieszkaniowej i obowiązku meldunkowego, o tyle z czasem większy akcent został położony na kwestie pomocy społecznej i spraw związanych z opieką medyczną. Oczywiście odmienną sprawą pozostają liczne interwencje podejmowane w latach 2005-2015 dotyczące poszczególnych problemów osób pozostających w kryzysie bezdomności lub narażonych na niego. Można zatem skonstatować, że bezdomność stanowi stałą kwestię w działalności Rzecznika, również katalog problemów - choć z czasem kładziono różnie akcenty - jest co do zasady niezmienny.

Syntetyczne poparcie tego wniosku może stanowić ustęp z „Oceny stanu przestrzegania wolności i praw człowieka i obywatela na 2013 rok”. Rzecznik stwierdzał w nim: „Wciąż nierozwiązany jest problem bezdomności, m.in. w aspekcie ochrony zdrowia (w tym dostępu do niezbędnej opieki medycznej), warunków pobytu w schroniskach, jak również braku regulacji, które w sposób szczegółowy określałyby zasady udzielania pomocy z uwzględnieniem potrzeby współpracy organów różnego szczebla"47. Podobna diagnoza rysuje się z informacji Rzecznika VII kadencji ${ }^{48}$. Podsumowując: stwierdzić należy zasadniczą ciągłość zainteresowania sprawami przeciwdziałania bezdomności w działalności RPO różnych kadencji. Organ ten w okresie 2005-2015 realizował funkcję ochronną i postulatywną w zakresie praw osób pozostających w kryzysie bezdomności. Obszarem, który - w związku z coraz większą wiedzą o bezdomności - wymaga aktywności Rzecznika, jest bezdomność długoterminowa.

47 «Biuletyn RPO. Źródła» 1/2014, s. 278.

48 «Biuletyn RPO. Źródła» 1/2017, s. 261-265. 
Skoro jednak analiza wskazała, że zakres poruszanych przez Rzecznika problemów jest zasadniczo niezmienny, to dlaczego tak się dzieje. Jak wskazano wcześniej, Rzecznik został prima facie wyposażony w bogate instrumentarium prawne zarówno o charakterze indywidualnym, jak i generalnym służące ochronie praw człowieka.

Wśród wymienianych form szczególne miejsce zajmuje obowiązek składania informacji - będący swoistym rocznym podsumowaniem pracy Rzecznika i jego Biura. Analizowane informacje wskazują, że Rzecznik korzystał głównie z takiego instrumentarium. Nie wykazywał jednak w swoich raportach znaczącego udziału w postępowaniach legislacyjnych. Okazuje się, że w analizowanym okresie była to wciąż stosunkowo rzadko wykorzystywana kompetencja w działaniach Rzecznika ${ }^{49}$.

Analiza informacji Rzecznika ukazuje niestety przykłady, gdy wystąpienia generalne do organów odpowiedzialnych za zmianę prawa pozostawały bez odpowiedzi lub odpowiedzi były zdawkowe. Istnieje znacząca dysproporcja między skutkami interwencji RPO a Trybunału Konstytucyjnego, czego przykładem jest opisywany problem wyroków eksmisyjnych. Zamiast rozwiązywać wiele problemów prawnych na poziomie diagnozy, RPO musi sięgać do swoistego ultima ratio w postaci wniosku do Trybunału Konstytucyjnego (jak w sprawie K 27/15). Stanowi to istotny wniosek o konieczności zmiany prawa w taki sposób, aby sięganie po instrument sądowego (tu trybunalskiego) rozstrzygania o kwestiach legislacyjnych było wynikiem swoistego sporu o prawo, a nie instrumentem sanowania bezczynności legislacyjnej prawodawcy.

Systemową bolączką obecnej regulacji prawnej dotyczącej Rzecznika jest brak odpowiedzialności za nieustosunkowanie się przez Sejm i Senat do diagnozowanych przez RPO niedomagań prawnych - której podsumowaniem jest coroczna informacja przedkładana obu Izbom. Postulat taki zgłaszał Rzecznik w 2015 r. podczas wystąpienia w Sejmie ${ }^{50}$. Można dostrzec tutaj dysproporcję pomiędzy obowiązkami i odpowiedzialnoś-

49 K. Nalaskowski, Sposób wykorzystania kompetencji przez Rzeczników w latach 1987-2007, [w:] Księga XX-lecia Rzecznika Praw Obywatelskich w Polsce, red. M. Zuвıк, Warszawa 2008, s. 162.

50 Sprawozdanie stenograficzne z 95. posiedzenia Sejmu Rzeczypospolitej Polskiej 24 czerwca 2015 r., s. 171. 
cią Rzecznika za stan ochrony praw człowieka w Polsce a podmiotami posiadającymi inicjatywę ustawodawczą, które powinny współdziałać z Rzecznikiem w tym zakresie. Co prawda zarówno Sejm, jak i Senat nie głosują za przyjęciem lub odrzuceniem informacji rocznej, jednak jest ona przedmiotem debaty parlamentarnej ${ }^{51} \mathrm{i}$ wadliwość tej informacji w skrajnych przypadkach może stać się podstawą zarzucenia Rzecznikowi sprzeniewierzenia się ślubowaniu (podstawa odwołania Rzecznika przed upływem kadencji).

Nie będzie przesadą powiedzieć, że odpowiedzialność jest tutaj właściwie jednostronna. Powoduje to stagnację w zakresie rozwiązania wielu problemów, pomimo ich dogłębnej, dawno temu dokonanej diagnozy prawnej (por. np. kolejne roczne raporty wskazujące na problemy w zakresie budownictwa socjalnego). Stan ten wymaga pilnej interwencji legislacyjnej.

Jakie zatem zmiany legislacyjne mogłyby przysłużyć się do sanacji wskazanych problemów? Oczywiście postulować można radykalne zmiany, wywierające wpływ na poszerzenie form działania Rzecznika, ale i konieczność daleko idących zamian konstytucyjnych, jak na przykład uregulowanie prawa RPO do bezpośredniej inicjatywy ustawodawczej. Tymczasem sytuację można próbować rozwiązać stosunkowo łagodniejszymi zmianami legislacyjnymi. Przede wszystkim chodzi o przepis zobowiązujący do poddania pod rozwagę odpowiednich komisji sejmowych wykazywanych przez RPO dysfunkcji prawnych. Nie chodzi jednak o samo przedstawienie informacji (to zresztą ma miejsce i obecnie), ale o autentyczny obowiązek prawny naprawy wykazywanych przez RPO dysfunkcji. Co więcej, informacja roczna RPO powinna być prawnie obiektem obligatoryjnego posiedzenia Rady Ministrów - organ ten w dzisiejszych warunkach jest przecież inicjatorem wielu zmian prawnych. Wymagana byłaby zatem zmiana obecnego art. 19 ustawy o RPO. Prawo nie może sprzyjać swoistemu „odbijaniu się” Rzecznika od „muru” niezrozumienia lub niechęci organów władzy publicznej, jeżeli tak charakteryzowane relacje się pojawią. Rzecznik strzeże bowiem

51 S. Trociuk, op. cit., przyp. 13. 
praw i wolności, które mogą być naruszone właśnie w wyniku podobnej negatywnej relacji władzy z jednostką.

Należy wyraźnie podkreślić, że Rzecznik stoi na straży wolności i praw człowieka i obywatela, w tym również na straży realizacji zasady równego traktowania. Polska, deklarując zasadę demokratycznego państwa prawnego, powinna należeć z innymi demokratycznymi państwami do grupy państw o podobnej aksjologii konstytucyjnej. Dostrzec jednak trzeba, że w globalnym świecie rozumienie wielu praw i wolności zmienia się, zmieniają się także formy ich realizacji i ochrony, a problemy stają się globalne. Zwróćmy uwagę, że RPO powinien współdziałać nie tylko z podmiotami niepublicznymi, lecz także organami i organizacjami międzynarodowymi (art. 17a ustawy o RPO). To ważny, jednak dość ogólny przepis wymagający moim zdaniem doprecyzowania. W tym kontekście warto odbyć dyskusję na temat postulowanej prawnej roli polskiego ombudsmana jako organu (niezależnie od osoby sprawującej tę funkcję), który nie jest wyłącznie strażnikiem określonych wolności i praw, ale autentycznym inicjatorem zmian prawnych, korzystającym powszechnie z doświadczeń innych państw w strzeżeniu wolności i praw człowieka i obywatela ${ }^{52}$. Bezdomność jako problem międzynarodowy jest jedną z takich płaszczyzn działania.

Działalność Rzecznika Praw Obywatelskich w Polsce W ZAKRESIE OCHRONY OSÓB W KRYZYSIE BEZDOMNOŚCI

I ZAGROŻONYCH BEZDOMNOŚCIĄ W LATACH 2005-2015 W ŚWIETLE RAPORTÓW RPO

\section{Streszczenie}

Celem artykułu jest ukazanie zainteresowania Rzecznika Praw Obywatelskich sprawami osób pozostających w kryzysie bezdomności i zagrożonych bezdomnością w latach 2005-2015. W związku z przyjętym celem zadano pytanie o swoistą stagnację w zakresie rozwiązywania

52 Należy z zadowoleniem podkreślić również aktywną rolę obecnego Rzecznika na tym polu, np. poprzez propagowanie Karty praw osób doświadczających bezdomności. 
wielu problemów bezdomności mimo wielokrotnej ich diagnozy przez RPO. W związku z założeniami formalnymi badaniu poddano dostępne Rzecznikowi instrumentarium prawne, a także sposoby jego wykorzystywania w odniesieniu do problemu bezdomności na przestrzeni kilkunastu lat. Ukazując faktyczną działalność Rzecznika, analizie poddano raporty dokumentujące jego aktywność. Analiza wykazała, że bezdomność stanowi od początku przedmiot zainteresowania RPO. $\mathrm{Na}$ przestrzeni lat diagnozowane problemy pozostają względnie niezmienne. Wskazuje to na nikłe oddziaływanie RPO na władzę ustawodawczą w analizowanym obszarze. Zdiagnozowano brak mechanizmów prawnych pozwalających wprost wymusić przez RPO zmiany prawne. Przekłada się to na niejako jednostronną prawną odpowiedzialność tego organu przy właściwie wyłącznie politycznej odpowiedzialności parlamentu za sprawy bezdomności.

The Work of the Polish OMbudsman IN 2005-2015 FOR The Protection of the Homeless and Persons in Danger of Homelessness, as Presented in the Ombudsman's Reports

\section{Summary}

This article presents the actions taken by the Polish Ombudsman in 2005-2015 on behalf of the homeless and persons facing the prospect of homelessness. The paper investigates the sluggishness in solving homelessness-related issues, despite the Ombudsman's clear and recurrent diagnoses of the situation. The analysis focuses on the legal instruments available to the Ombudsman and their applicability in issues relating to homelessness and its prevention. An account of the work of Polish ombudsmen is provided in their reports, which show that they have always recognised homelessness as a legitimate sphere of their interest and activities. However, these issues, which have not changed much over the years, have generally not been addressed and are still unresolved. The paper shows that as regards the homeless, the Polish Ombudsman has only a limited amount of influence with the legislative authority. There are no legal instruments which he can apply to foster changes in 
the law. This burdens the Ombudsman with a unilateral legal responsibility, while effectively the Polish parliament carries only the political responsibility for policies on the prevention of homelessness.

Słowa kluczowe: bezdomność; rzecznik praw obywatelskich; prawa człowieka.

Keywords: homelessness; ombudsman; human rights.

\section{Literatura}

BANASzak N., Skuteczność działania Rzecznika Praw Obywatelskich - podstawowe problemy, «Studia Lubuskie» 5/2009, s. 63-80.

BŁAszczaK A., Efektywność środków ochrony przed dyskryminacja w Polsce, «PiP» 70.6/2015, s. 37-50.

CEndrowicz D., Osoba bezdomna jako element społecznego otoczenia administracji publicznej, "Acta Universitatis Vratislaviensis. Przegląd Prawa i Administracji» 111/2017, s. 13-27.

Jagielski J., Wierzbowski M. (red.), Prawo administracyjne. Dziś i jutro, Warszawa 2018.

Kijowski D.J., Suwaj P.J. (red.), Kryzys prawa administracyjnego, Warszawa 2012.

Lipowicz I., Kilka uwag $w$ kwestii racjonalności w prawie administracyjnym, [w:] Racjonalny ustawodawca. Racjonalna administracja. Pamięci Profesora Eugeniusza Smoktunowicza, red. D.J. Kijowski, A. Miruć, A. Budnik, Białystok 2016, s. 63-72.

Malinowska I., Rzecznik Praw Obywatelskich w systemie ochrony wolności i praw obywatelskich, Warszawa 2007.

MęDRZYCKi R., Zadania administracji publicznej w zakresie przeciwdziałania bezdomności - studium administracyjnoprawne, Warszawa 2017.

Nalaskowski K., Sposób wykorzystania kompetencji przez Rzeczników w latach 1987-2007, [w:] Księga XX-lecia Rzecznika Praw Obywatelskich w Polsce, red. M. Zuвıк, Warszawa 2008, s. 151-165.

Miruć A., Współdziałanie podmiotów zajmujacych siępomoca społeczna, [w:] Formy współdziałania jednostek samorządu terytorialnego, red. B. DoLNICKI, Warszawa 2012, s. 52-71.

Przymeński A., Bezdomność jako kwestia społeczna w Polsce współczesnej, Poznań 2001. 
Szubia kowski M., Administracyjnoprawna regulacja praw i wolności obywatelskich, Warszawa 2017.

Trocıuк S., Rzecznik Praw Obywatelskich. Komentarz, Warszawa 2007.

WróBlewsкi M., Ochrona praw osób starszych w działalności Rzecznika Praw Obywatelskich jako krajowej instytucji ochrony praw człowieka, «RPEiS» 74.3/2012, s. 123-138.

ZAGóRsKI J., Wykonywanie środków probacji i readaptacji skazanych w Polsce, Warszawa 2008.

Zimmermann J., Aksjologia prawa administracyjnego, Warszawa 2016.

Zuвік M., Rzecznik Praw Obywatelskich (po 20 latach istnienia urzędu), «PiP» 63.11/2008, s. 3-19. 